\title{
Therapeutic effectiveness of rat bone marrow stem cells in Poly Cystic Ovary Syndrome Mice Model on folliculogenesis, TGF-ק, GDF-9 expression, and estrogen, TNF- $\alpha$ and androgen Levels
}

\author{
Budi S', Agus S', Salmon Charles S', Widjiati \\ 'Department of Obstetrics and Gynecology, Faculty of Medicine, ${ }^{2}$ Department of Microbiology, \\ Faculty of Veterinary Medicine, Universitas Airlangga, Dr Soetomo Hospital, Surabaya, Indonesia
}

\begin{abstract}
ABSTRAK
Tujuan: mengidentifikasi efektivitas terapi Rat Bone Marrow stem sel pada tikus model PCOS terhadap folikulogenesis, ekspresi TGF- $\beta$ dan GDF-9 serta terhadap kadar estrogen, TNF- $\alpha$ dan androgen.

Bahan dan Metode: Penelitian ini merupakan penelitian eksperimental laboratorium menggunakan hewan coba. SOPK diinduksi dengan pemberian hormone testosterone provionat, pada 30 ekor tikus. Subjek penelitian dibagi menjadi 2 kelompok: kontrol dan perlakuan diberi sel punca. Penyuntikan sel punca dilakukan pada tikus perlakuan, kemudian dilakukan pemeriksaan dengan swab vagina. Pemeriksaan TNF- $\alpha$ dengan menggunakan imunohistokimia dan pemeriksaan kadar androgen dengan menggunakan ELISA. Data dibandingkan dengan student t-test.

Hasil: jumlah rerata ekspresi $\mathrm{TNF} \alpha$ pada kelompok perlakuan lebih rendah dibandingkan dengan kelompok perlakuan (kontrol 5,35 vs perlakuan 2,34 , Sig 0,0026). Jumlah rerata kadar androgen pada perlakuan lebih rendah dibandingkan dengan rerata apda kontrol (kontrol 2,31 VS perlakuan 0,40, Sig 0,0026).

Simpulan: pada percobaan tikus SOPK,sel punca menurunkan ekspresi TNF $\alpha$ dan kadar androgen.
\end{abstract}

\begin{abstract}
Objectives: to identify therapeutic effectiveness of Rat Bone Marrow stem cell in PCOS rats model on folliculogenesis, TGFbeta and GDF-9 expression and on estrogen, TNF- $\alpha$ and androgen levels.

Material and Methods: this study is a laboratory experimental research with using animal testing. PCOS was induced by the administration of testosterone propionate hormone into 30 mice. The subjects of this study are divided into 2 groups: stem cell group and control group. The mice were injected with testosterone then vaginal swab was performed to determine the mice cycle. After determining mice in anestrous cycle, stem cell was injected. TNF- $\alpha$ was measured with immunohistochemistry and androgen was examined using ELISA. The data was measured by student $\mathrm{t}-$ test.

Result: The average number of TNF- $\alpha$ expression in control group was lower than stem cell group (5.35 vs $2.34 ; \mathrm{p}=0.0026$ ). The average androgen level for stem cell group was lower than mean for control group (2.31 vs $0.40 ; \mathrm{p}=0.0026)$.

Conclusion: In this study of polycystic model mice, stem cell decreased the expression of TNF- $\alpha$ and androgen level
\end{abstract}

Keywords: stem cell, PCOS, TNF- $\alpha$, androgen level

Kata kunci: sel punca, $\mathrm{SOPK}, \mathrm{TNF} \alpha$, kadar androgen

Correspondence: Budi Santoso, Department of Obstetrics and Gynecology, Faculty of Medicine, Airlangga University, Dr Soetomo Hospital, Jalan Prof dr Moestopo 6-8, Surabaya 60286. Phone: 62-8123581706, email: busobg98@yahoo.com

\section{INTRODUCTION}

Poly Cystic Ovarian Syndrome (PCOS) is the most common endocrine disorder in women within their reproductive age with a prevalence of $4-12 \%$. PCOS itself is a heterogeneous problem with extremely complex symptoms (Sheehan, 2004)

Stem cells have the ability to differentiate into other cells and develop into various types of mature cells. Furthermore, stem cell is able to regenerate itself or make a copy of cells identical to themselves through cell division (Saputra, 2006). Bone Marrow Stem Cell therapy is used as a carrier of transgene or cells into the body because these stem cells have the ability to express a gene or a specific cell in the body. Bone Marrow Stem Cell has the properties of self-renewing, so that the administration of therapy does not need to be repeated. In addition, the characteristic of hematopoietic stem cells is also able to differentiate into other types of cells, so the cells can settle in various types of cells and repairing damaged cells through cell division process (Fungi et al., 2001).

In the case of PCOS, Tumor Necrosis Factor $\alpha$ plays an important role in the process insulin resistance. The discovery of TNF $\alpha$ in adipose tissue, especially in obese patients, proves that TNF- $\alpha$ plays an important role in the pathogenesis of PCOS.(Samy., 2009)

Therefore Bone Marrow Stem Cell therapy for PCOS needs to be reviewed in biomolecular reproduction field to reveal the mechanism of folliculogenesis and egg cell maturation as an evidence basis for scientific study. This study is using rats as animal model of PCOS 
solely because of ethical factors and to make the research easier.

\section{MATERIAL AND METHODS}

This study was an experimental laboratory research with double blind randomized design. The population in this study was mice (Mus musculus) from animal unit laboratory. To create the mice model of PCOS, testosterone propionate were injected with a dose of 100 $\mathrm{mg} / \mathrm{kgbw}$ for 14 days. After that vaginal swab examination was performed to determine the estrous cycle of mice, on day 15 . In mice with PCOS, on the 15 th day the vaginal swab will appear as diestrous phase. Vaginal swab was performed in PCOS mice model by inserting wet cotton into the vagina and twisting it around, then it was applied to the object glass. After that, it was fixed with $70 \%$ alcohol for 5 minutes. The Giemsa dye was dripped on the object glass for 2-3 minutes, then it was washed with water and dried. Then it was examined under microscope to determine the stage of estrous cycle including proestrous, estrous, metestrous and diestrous.

Mouse's bone marrow was isolated. MEM medium was added and then centrifuged at $3000 \mathrm{rpm}$ for 10 minutes and was repeated up to 2 times. The precipitate was then cultured in MEM medium and added with antibiotic, anti-fungal and 15\% Fetal Calf Serum (FCS). Pasese performed repeatedly until a cell line was formed. PCOS mice models were treated with Rat Bone Marrow Stem Cell cultures derived from rat bone marrow conducted in Tropical Disease Research Centre, University of Airlangga. Injections were given in a single dose at a dose of $10 \%$ mouse. Intravenous injecttions were injected on the tail. Before injections, the tail was warmed therefore there the tail's blood vessel was dilated. PCOS rat model's vagina was swabbed after Rat Bone Marrow Stem Cell therapy, a wet cotton was inserted in the vagina and twisted around, then applied to the object glas. Then it was fixed with $70 \%$ alcohol for 5 minutes. Then object glass was dripped with Giemsa dye, it was for 2-3 minutes, then washed with water and dried subsequently examined under microscope to determine the stage of the estrous cycle such as proestrous, estrous, metestrous and diestrous.

Ovarian tissues were fixed on an object glass, paraffinization, deparaffinization and coating process with a secondary antibody were then performed. After that TNF Alpha monoclonal antibody was washed and coated to determine the location of the hyaluronan receptor. Counterstaining used was commasie blue
Immunohistochemistry method used is the avidin biotin model and antibodies. Ovarium tissue was taken and serially selected to get the number of follicles and its morphology. In situ hybridization (ISH) was conducted to determine the location of the tissue and $17 \alpha-$ hydroxylase $(17 \alpha-\mathrm{OH})$ mRNA level. Then ELISA examination was performed.

This research was conducted in 2014 in In Vitro Fertilization Laboratory of the Faculty of Veterinary Medicine Airlangga University. Ethical eligibility of this study was approved by the Ethics Committee of the Faculty of Veterinary Medicine, Airlangga University Surabaya

\section{RESULT AND DISCUSSION}

PCOS modeling was done by injection of testosterone propionate in female mice with $100 \mathrm{mg} / \mathrm{kg}$ dose for 14 days. On day 15 , the mice's vagina was swabbed to observe the estrous cycle after being injected with testosterone propionate. Vaginal swab test results of all the mice were in diestrous phase. Data of the vaginal swab results were presented in Table 1.

Table 1. Percentage of estrous cycle in PCOS rat model before and after RBMSC therapy

\begin{tabular}{lllll}
\hline \multirow{2}{*}{ Group } & \multicolumn{3}{c}{ Sexual arousal cycle } \\
\cline { 2 - 5 } & Proestrous & Estrous & Metestrous & Diestrous \\
\hline Control & $0(0 \%)$ & $0(0 \%)$ & $0(0 \%)$ & $15(100 \%)$ \\
$\begin{array}{l}\text { RBMSC } \\
\text { treatment }\end{array}$ & $8(53.4 \%)$ & $4(26.4 \%)$ & $0(0 \%)$ & $3(20 \%)$ \\
\hline
\end{tabular}

After the PCOS animal models were treated with Rat Bone marrow Stem Cell with dose of $1 \times 10^{6} /$ mouse and the reproductive cycle was examined, the results were that all of the control group who did not receive Rat Bone Marrow Stem Cell therapy 100\% were on diestrous phase. The treatment group were treated Rat Bone Marrow Stem Cell, the reproductive cycle of most animals turn into a model of PCOS proestrus phase (53.4\%) and estrus (26.4\%), although a small portion remains in the diestrus phase of (20\%). This shows that the administration of Bone Marrow Stem Cell therapy can improve the reproductive cycle. Data from the vaginal swab of PCOS animal models after treatment with Rat Bone Marrow Stem Cell was presented in Table 1 above.

Folliculogenesis examination results with Haematoxillin eosin staining of PCOS rat model's ovarium can be seen in Table 2. 
Table 2. Data of the development of follicles in the ovaries of PCOS Model Rats after treated with Rat Bone Marrow Stem Cell

\begin{tabular}{lcccc}
\hline \multirow{2}{*}{ Group } & \multicolumn{4}{c}{$(\mathrm{X} \pm \mathrm{SD})$} \\
\cline { 2 - 5 } & $\begin{array}{c}\text { Primary } \\
\text { follicle }\end{array}$ & $\begin{array}{c}\text { Secondary } \\
\text { follicle }\end{array}$ & $\begin{array}{c}\text { Tertiary } \\
\text { follicle }\end{array}$ & $\begin{array}{c}\text { Follicles De } \\
\text { Graff }\end{array}$ \\
\hline Control & $1.93 \pm 1.03^{\mathrm{a}}$ & $1.80 \pm 1.45^{\mathrm{a}}$ & $0.93 \pm 0.59^{\mathrm{a}}$ & $0.07 \pm 0.02^{\mathrm{a}}$ \\
Treatment & $2.80 \pm 1.01^{\mathrm{b}}$ & $2.87 \pm 1.59^{\mathrm{b}}$ & $3.40 \pm 1.84^{\mathrm{b}}$ & $1.07 \pm 0.07^{\mathrm{b}}$ \\
\hline Description: different superscript in the same column shows the significant differences
\end{tabular}

Statistical analysis of the results showed that the rat model of PCOS after getting Rat Bone Marrow Stem Cell was significantly different compared with the control group of PCOS mice model that was not treated with Bone Marrow Stem Cell.

Expression of Tumor Necrosis Alpha in each sample was assessed semiquantitatively according to the modified method Remmele (Novak et al., 2007). Index scale Remmele (IRS) is the multiplication of immunoreactive cell expressing TNF- $\alpha$ percentages score to the intensity of the color produced on the cell score. The effect of Rat Bone Marrow Stem Cell therapy in PCOS mice models through immu-nohistochemistry staining, counted semiquantitatively, can be seen in Table 3 .

From the analysis of calculations performed with Kruskal Wallis test to the overall treatment, the results obtained were significantly different $(p<0.05)$. If the result of the analysis was significantly different then the non-parametric test comparison Mann-Whitney test was performed to show the significant differences between two treatments ( $\mathrm{p}<0.05)$, it meant that there was a difference between control and treatment groups in the expression of T NF- $\alpha$ in the ovary.

Table 3. Mean of the expression of TGF- $\beta$ in PCOS Rat Model's ovaries after treatment with Rat Bone Marrow Stem Cel

\begin{tabular}{ccc}
\hline \multicolumn{2}{c}{ Mean value } & \multirow{2}{*}{ Sig } \\
\cline { 1 - 2 } Control & Treatment & \\
\cline { 1 - 2 } 5.35 & 2.34 & $0.0026^{*}$ \\
\hline
\end{tabular}

On the Mann-Whitney test control and treatment groups had a significant difference. This indicated that between control and treatment groups the expression of TNF$\alpha$ were different and the treatment gave a noticeable effect. It appeared also on the average results of the expression of TNF- $\alpha$, it showed that the average difference in expression of TNF- $\alpha$ in treatment group was greater (2.34) than control.

Androgen levels in each sample assessed semiquantitatively according to the modified method Remmele (Novak et al., 2007 Index scale Remmele
(IRS) is the multiplication of immunoreactive cell expressing TNF- $\alpha$ percentages score to the intensity of the color produced on the cell score (Appendix 1). The effect of Rat Bone Marrow Stem Cell therapy in PCOS mice models through immunohistochemistry staining, counted semiquantitatively, can be seen in Table 3

From the analysis of calculations performed with Kruskal Wallis to the overall treatment, the results obtained are significantly different $(p<0.05)$. ). If the result of the analysis was significantly different then the non-parametric test comparison Mann-Whitney test was performed to show the significant differences between 2 treatments $(\mathrm{p}<0.05)$, it meant that there was a difference between control and treatment groups in the expression of androgen levels in the ovary.

Table 4. The mean value of ELISA Androgens in PCOS Rat Model's ovaries after treatment with Rat Bone Marrow Stem Cell

\begin{tabular}{lll}
\hline \multicolumn{2}{c}{ Mean value } & Sig \\
\cline { 1 - 2 } Control & Treatment & \\
\hline 2.31 & 0.40 & $0.0026 *$ \\
\hline
\end{tabular}

Mann-Whitney test between control and treatment groups had significant differences. This indicated that between control and treatment groups there were different androgen ELISA mean value and the treatment gave a noticeable effect. It appeared also on the average results of androgen ELISA, it showed that the average difference of androgen ELISA in treatment group was greater (2.34) than control.

\section{CONCLUSION}

As the study ended it can be concluded that the stem cells in PCOS will improve folliculogenesis and improvement of inflammatory mediators TNF $\alpha$ and improved levels of androgen.

\section{REFERENCES}

1. Balen AH, Conway $\mathrm{G}$, Hombarg $\mathrm{R}$ and $\mathrm{RS}$ Legro. Polycystic ovary. Simdrome, a Guide to 
Clinical Management. Taylor and Francis, Boca Raton. 2005:1-14.

2. Budi S, Prajitno RP, Soetjipto, Widjiati. The Comparation Activity of MMP-9 and TIMP-1 activity to increasing Collagen-4 Expresion in Model Polycystic ovary syndrome and the one with normal estrus cyclephase. National Seminar of Translational, Faculty of Medicine Airlangga University 126. 2008.

3. Mushrooms MC, Grodzki ACG, Moreno AN, deMello LFC, Pastor MVD, Berenstein EH, Siraganian RFP and Oliver C. Identification and isolation of rat bone marrow-derivet mast cells using the mast cell-specific monoclonal antibody AA4. J of Histochemistry and Cytochemistry. 2001;49(920):219-28.

4. Karnen GB. Basic Immunology, Reproductive Immunology. Hall Publisher FK UI. Jakarta. 2006.

5. Lee HJ, Selesmiami K, Niikura $Y$, Niikura $T$, Klein R, Dombkowski DM and Tilly JL. Bone marrow transplantation generates immature oocytes and rescues long-term fertility in a preclinical mouse models of chemotherapy indued premature ovarian failure. 2007;25(22):3198-204.

6. Massague J. Transforming growth factor beta signaling tranduction. Annu. Rev. Biochem. 1998; 67:753-91.

7. May JV, Stephenson LA, Turzcynski CJ, Fong HW, Mau YM and Davis JS. Transforming growth factor beta expression in the ovary porcein, evidence that theca cells are the major secretory antral folicle source during development. J. Biol. Reprod. 1996;54: 485-96.

8. Österlund C and Fried G. TGF $\beta$ receptors I and II and the substrate protein Smad 2 and 3 are present in human oocyte. J. Mol. Hum. Reprod. 2000;6(6):498-503.

9. Saputra V. Stem Cell Basics and potential applications in medicine. Mirror medicine. 2006;153:215.

10. Sheehan MT. Polycystic Ovarian Syndrome: Diagnosis and management. Clinical Medecine and Research. 2004;2(1):13-27.

11. Speroff 1 and MA Frizt. anovulation and polycystic ovary. In: Clinical Gynecologic Endocrinology and Infertility. 7th Eds. Philadel-phia: Lippincott William and Wilkins; 2005. p. 465-98.

12. Steel RGD and Torrie JH. Principles and procedures Statistics. Jakarta: PT. Gramedia; 1991.

13. Tolliver DK and Robbins LW. Techniques in karyology: The bone marrow extraction method. Association for biology laboratory, Missouri. 1991.

14. Its $\mathrm{P}$ and Roy SK. Epidermal growth factor receptor modulates transforming growth factor messenger RNA and protein levels in hamsters preanthral follicles in vitro. J. Biol. Reprod. 2001; 65:847-54. 